\title{
PENINGKATAN HASIL BELAJAR SISWA KELAS V SD MATERI VOLUME BANGUN RUANG KUBUS DAN BALOK MELALUI MODEL EXPERIENTAL LEARNING
}

\author{
Novia Ramadhani Yuwono ${ }^{1}$, Suhel Madyono $^{2}$, Yuniawatika ${ }^{3}$ \\ ${ }^{1,2,3}$ Universitas Negeri Malang - Jl. Semarang No.5 Kota Malang, 65145, Indonesia \\ noviaramadhaniyuwono@gmail.com ${ }^{1}$ suhel.madyono.um.ac.id ${ }^{2}$, yuniawatika.fip@um.ac.id ${ }^{3}$
}

\begin{abstract}
This study aims to improve the learning outcomes of the cubic and block volume shapes through experiential learning models. This type of research is a classroom action research consisting of two cycles. Each cycle consists of planning, implementing, observing, and reflecting. The results showed that teacher activity increased from cycle I, namely $82 \%$ to $94.5 \%$. Student activity has increased from $80 \%$ to $91 \%$. The learning outcomes of the knowledge aspect in cycle I to cycle II have increased with classical learning completeness from $82 \%$ to $100 \%$. It can be concluded that the experiential learning model can improve student learning outcomes.
\end{abstract}

Keywords: learning outcomes, volume, building space, experiental learning

\begin{abstract}
Abstrak: Penelitian ini bertujuan untuk meningkatkan hasil belajar volume bangun ruang kubus dan balok melalui model experiental learning. Jenis penelitian ini adalah penelitian tindakan kelas yang terdiri dari dua siklus. Setiap siklus terdiri dari perencanaan, pelaksanaan, pengamatan, dan refleksi. Hasil penelitian menunjukkan bahwa aktivitas guru meningkat dari siklus I yaitu $82 \%$ menjadi $94.5 \%$. Aktivitas siswa mengalami peningkatan dari $80 \%$ menjadi $91 \%$. Hasil belajar aspek pengetahuan pada siklus I ke siklus II mengalami peningkatan dengan ketuntasan belajar klasikal dari 82\% menjadi 100\%. Dapat disimpulkan bahwa model experiental learning dapat meningkatkan hasil belajar siswa.
\end{abstract}

Kata kunci: hasil belajar, volume, bangun ruang, experiental learning

Pembelajaran matematika yang baik untuk siswa sekolah dasar adalah pembelajaran yang mengkontruksi pengetahuan matematika. Menurut (Retnowati and Budi 2013) pembelajaran matematika seharusnya berpusat pada siswa, bukan pada guru. Oleh karena itu, keterlibatan siswa secara aktif sangat penting dalam kegiatan pembelajaran. Pembelajaran matematika khususnya materi geometri di sekolah dasar berhubungan dengan benda-benda nyata yang biasa mereka temui. Pelaksanaan pembelajaran sebaiknya dibantu menggunakan media kontekstual yang bisa mendukung proses belajar siswa secara aktif dengan mengedepankan pengalaman belajar langsung oleh siswa. Hal ini sejalan dengan (Perdana, Zainuddin, and Yuniawatika 2018) pencapaian hasil belajar yang baik sangat erat kaitannya dengan upaya untuk memahami matematika melalui pemecahan masalah yang konkret dan kontekstual. Namun, faktanya selama ini masih banyak ditemukan berbagai permasalahan, baik dari sisi guru maupun siswa yang mempengaruhi hasil belajar siswa.

Berdasarkan wawancara dan observasi hasil belajar siswa kelas $\mathrm{V}$ pada pembelajaran matematika masih rendah. Permasalahan yang dialami siswa terhadap konsep volume ruang kubus 
dan balok yaitu siswa hanya menghafal rumus saja, sedangkan penerapan dalam memecahkan suatu permasalahan dalam bentuk soal cerita siswa kesulitan dalam memecahkan permasalahan tersebut. Perolehan hasil belajar siswa pada mata pelajaran matematika yang rendah tersebut bisa disebabkan karena penggunaan metode atau model yang kurang sesuai dengan karakteristik siswa dan mata pelajaran. Sehingga dalam menyampaikan materi pelajaran, guru dapat menggunakan strategi, metode, maupun model yang tepat dan dibantu media yang mendukung kegiatan belajar mengajar agar dapat meningkatkan hasil belajar siswa.

Hasil pratindakan yang dilaksanakan tanggal 1 Februari 2018, menunjukkan hasil belajar siswa pada mata pelajaran matematika masih kurang maksimal. Dari 17 siswa hanya 6 siswa yang dapat mencapai Kriteria Ketuntasan Minimal (KKM) yang ditentukan yaitu 72, sedangkan 11 siswa lainnya belum mencapai KKM.

Permasalahan pembelajaran yang terjadi pada pembelajaran matematika pada siswa kelas V SDN Babadan 02 Kabupaten Blitar, dapat diatasi salah satunya dengan menerapkan model pembelajaran experiental learning. Solusi ini dipilih karena model pembelajaran experiental learning dapat memberikan kesempatan kepada siswa untuk belajar melalui pengalamannya. Melalui pengalaman langsung dapat meningkatkan partisipasi siswa dalam belajar, mengembangkan potensi yang dimiliki siswa dan siswa dapat menerapkannya untuk kehidupan sehari-hari.

Hal ini dibuktikan dari penelitian yang sudah dilakukan oleh (Lestari 2017). Penelitian tersebut dilaksanakan di kelas IV SDN 2 Gandusari Kabupaten Trenggalek tahun pelajaran 2016/2017. Dari penelitian tersebut menunjukkan peningkatan hasil belajar siswa dilihat dari tiga aspek penilaian. Hasil belajar aspek pengetahuan pada tahap pratindakan mencapai nilai rata-rata 65,94 dan ketuntasan klasikal 62,5\%. Setelah dilaksanakan siklus 1, hasil belajar aspek pengetahuan mencapai rata-rata 71,59 dan ketuntasan klasikal menjadi $72 \%$. Selanjutnya pada siklus II, nilai ratarata mencapai 89,5 dan ketuntasan klasikal men-capai 100\%. Aspek keterampilan dan sikap dari siklus I sampai II juga mengalami peningkatan (Lestari 2017).

Berdasarkan hasil penelitian di atas bahwa pembelajaran dengan menerapkan model experiental learning dapat meningkatkan hasil belajar siswa, maka dilakukan penelitian tindakan kelas dengan judul "Peningkatan Hasil Belajar Siswa Kelas V SD Materi Volume Bangun Ruang Kubus Dan Balok Melalui Model Experiental Learning".

\section{METODE}

Pendekatan yang digunakan dalam penelitian ini adalah pen-dekatan kualitatif. Jenis penelitian yang digunakan adalah Penelitian Tindakan Kelas (PTK). Penelitian tindakan kelas ini dilaksanakan bertujuan untuk memperbaiki dan me-ningkatkan hasil belajar pada pem-belajaran matematika materi volume bangun ruang kubus dan balok pada siswa kelas V SDN Babadan 02 Kabupaten Blitar dengan meng-gunakan model experiental learning.

Model PTK yang digunakan dalam penelitian ini mengacu pada model Kemmis dan Taggart (Arikunto and Suhardjono 2014). Penelitian dilaksanakan sebanyak 2 siklus, tiap siklus terdiri dari 2 pertemuan. Masing-masing siklus terdiri dari empat langkah, yaitu 1) perencanaan, 2) pelaksanaan, 3) pengamatan, dan 4) refleksi.

Subjek dalam penelitian ini adalah siswa kelas V di SDN Babadan 02 Kabupaten Blitar semester II tahun pelajaran 2017/ 2018. Siswa kelas V terdiri dari 17 siswa yang terdiri dari 12 siswa laki-laki dan 5 siswa perempuan.

Jenis data penelitian yang dikumpulkan ada dua, yaitu data proses dan data hasil belajar. Data proses diperoleh dari hasil observasi aktivitas guru dan siswa selama proses pembelajaran berlangsung. Data hasil belajar diperoleh dari data penilaian ranah pengetahuan dan keterampilan. 
Sumber data dalam penelitian ini adalah siswa kelas V SDN Babadan 02 Kabupaten Blitar dan guru model.

Teknik pengumpulan data meliputi wawancara, observasi, tes, catatan lapangan, dan dokumentasi. Adapun teknik analisis data teknik analisis data kualitatif. Analisis data kualitatif menggambarkan kenyataan sesuai dengan data yang diperoleh untuk mengetahui keefektifan model pembelajaran experiental learning dalam meningkatkan hasil belajar materi volume bangun ruang kubus dan balok. Ada 3 tahapan dalam analisis data kualitatif, yaitu: 1) reduksi data, 2) penyajian data, dan 3) kesimpulan (Sugiyono 2015).

Analisis data, evaluasi, dan refleksi dilaksanakan dari awal hingga akhir kegiatan penelitian. Analisis diawali dengan pengumpulan data dari hasil wawancara, observasi, tes evaluasi, dan catatan lapangan, serta dokumentasi.

Data hasil observasi aktivitas guru, aktivitas siswa, hasil belajar siswa aspek keterampilan dan pengetahuan siswa selama pembelajaran dihitung berdasarkan rumus yang ditentukan.

Kemudian penarikan kesimpulan siswa dikelompokkan antara siswa yang mendapatkan nilai diatas rata-rata dengan kategori tuntas dan belum tuntas belajar, baik secara individu maupun klasikal. Siswa dikatakan tuntas secara individu apabila nilainya mencapai KKM yang ditentukan yaitu 72, sedangkan siswa yang belum tuntas apabila nilainya di bawah KKM. Ketuntasan klasikal, ditentukan minimal $80 \%$ siswa di kelas tuntas belajar. Jika kurang dari $80 \%$, maka perlu adanya tindakan pada siklus berikutnya.

\section{HASIL}

Hasil observasi pembelajaran pada pratindakan yang dilaksanakan oleh guru kelas, diperoleh informasi hasil belajar siswa yang masih rendah. Dari 17 siswa hanya 6 siswa (35\%) yang memperoleh nilai di atas KKM yang ditentukan yaitu 72, sementara 11 siswa (65\%) lainnya memperoleh nilai di bawah KKM. Perolehan hasil belajar pada tahap pratindakan masih dalam kriteria sangat kurang dengan rata-rata nilai mencapai 53, nilai tersebut masih di bawah nilai KKM. Nilai ketuntasan belajar siswa hanya 35\% dari ketuntasan belajar minimal $80 \%$. Solusi yang bisa dilakukan untuk mengatasi hal ini yaitu dengan melaksanakan pembelajaran siklus 1 untuk mata pelajaran matematika dengan materi volume bangun ruang kubus dan balok dengan menerapkan model pembelajaran experiental learning.

Hasil observasi terhadap aktivitas guru pada siklus I pertemuan 1 diperoleh persentase aktivitas guru $80 \%$ dengan kriteria keberhasilan baik. Pada pertemuan 2 aktivitas guru $84 \%$ dengan kriteria keberhasilan baik. Setelah dirata-rata persentase aktivitas guru dari dua pertemuan tersebut sebesar $82 \%$ dengan kriteria keberhasilan baik.

Data hasil observasi aktivitas siswa pada siklus I pertemuan 1 mencapai 76\% dengan kriteria keberhasilan cukup. Pada pertemuan 2 mencapai 84\% dengan kriteria keberhasilan baik. Setelah dirata-rata persentase aktivitas siswa dari dua pertemuan tersebut sebesar $80 \%$ dengan kriteria keberhasilan baik.

Hasil belajar siswa aspek pengetahuan, rata-rata nilai akhir pembelajaran pertemuan 1 dan pertemuan 2 pada siklus I adalah 80,5. Ketuntasan klasikal sebesar 82\%, artinya dari 17 siswa sebanyak 14 siswa dinyatakan tuntas dengan memperoleh nilai $\geq 72$. Sedangkan siswa yang belum tuntas yaitu sebesar $18 \%$, artinya ada 3 siswa belum mencapai ketuntasan.

Persentase ketuntasan aspek keterampilan pada siklus I pertemuan 1 sebesar $64 \%$ dengan kriteria keberhasilan kurang. Pada pertemuan 2 meningkat menjadi $70 \%$ dengan kriteria keberhasilan cukup. Setelah dirata-rata persentase aspek keterampilan siklus I dari dua pertemuan tersebut sebesar $67 \%$ dengan kriteria keberhasilan kurang. 
Berdasarkan data hasil observasi siklus I pertemuan 1 dan pertemuan 2, dapat direfleksikan sebagai berikut: 1) guru kurang tegas dan kurang mampu mengkondisikan kelas, 2) guru melewatkan penyampaian tujuan pembelajaran sebelum memasuki kegiatan inti, 3) pada kegiatan inti, kekurangan dari aktivitas guru yaitu guru kurang memantau setiap kelompok secara merata, 4) permasalahan yang terjadi dari aktivitas siswa yaitu siswa masih belum terbiasa bekerjasama dalam kelompok, 5) pada saat pembagian media pembelajaran, situasi kondusif siswa terpecah karena siswa tertarik dengan media kubus coklat yang dibagikan, siswa juga masih menggunakan media untuk bermain-main, 6) pada kegiatan akhir, guru tidak melakukan tanya jawab dengan siswa tentang materi yang belum dipahami, dan 7) rata-rata hasil belajar yang diperoleh siswa pada siklus I telah mencapai target yang telah ditentukan, tetapi ada beberapa siswa masih mendapat hasil belajar di bawah KKM yang ditentukan. Oleh sebab itu, kekurangan dan permasalahan yang ditemui pada siklus I perlu diperbaiki dan diadakan tindak lanjut untuk pertemuan berikutnya pada siklus II agar mencapai hasil yang maksimal.

Hasil observasi terhadap aktivitas guru pada siklus II pertemuan 1 mencapai 93\% dengan kriteria sangat baik. Pada pertemuan 2 meningkat menjadi 96\% dengan kriteria sangat baik. Setelah dirata-rata persentase aktivitas guru dari dua pertemuan tersebut mencapai $94.5 \%$ dengan kriteria sangat baik.

Data hasil observasi aktivitas siswa pada siklus II pertemuan 1 mencapai 86\% dengan kriteria baik. Pada pertemuan 2 meningkat menjadi 96\% dengan kriteria keberhasilan sangat baik. Setelah dirata-rata dari dua pertemuan tersebut menjadi $91 \%$ dengan kriteria keberhasilan sangat baik.

Data hasil belajar siswa aspek pengetahuan, rata-rata nilai akhir pembelajaran pada pertemuan 1 dan pertemuan 2 pada siklus II adalah 90.8. Persentase ketuntasan klasikal mencapai $100 \%$, artinya seluruh siswa dinyatakan tuntas dengan memperoleh nilai $\geq 72$.

Persentase aspek keterampilan pada siklus II pertemuan 1 sebesar 76\% dengan kriteria cukup. Pada pertemuan 2 meningkat menjadi 94\% dengan kriteria sangat baik. Setelah dirata-rata persentase aspek keterampilan siklus II dari dua pertemuan tersebut menjadi $85 \%$ dengan kriteria baik.

Berdasarkan observasi yang dilakukan pada siklus II pertemuan 1 dan pertemuan 2 diperoleh data sebagai berikut: 1) guru telah me-laksanakan pembelajaran dengan baik dan sesuai dengan langkah-langkah pembelajaran menggunakan model experiental learning seperti yang tertulis di RPP yang telah disiapkan, 2) kekurangan pada siklus I sudah diperbaiki pada siklus II, 3) peningkatan aktivitas guru, yang dibuktikan dari rata-rata persentase aktivitas guru mencapai $94.5 \%, 4)$ pada siklus II ini, guru mulai dapat mengkondisikan siswa dengan meng-antisipasi permasalahan yang muncul pada siklus I yaitu permasalahan terpecahnya suasana kondusif belajar siswa karena coklat kubus, 5) aktivitas siswa selama kegiatan pembelajaran berlangsung juga telah mengalami peningkatan, 6) siswa mengikuti pembelajaran dengan baik, mendengarkan petunjuk dan bimbingan guru dengan baik, serta siswa sudah mampu bekerjasama dengan kelompoknya, 7) peningkatan aktivitas siswa mencapai rata-rata 91\%,8) hasil belajar siswa pada siklus II ini mengalami peningkatan dibandingkan siklus I, persentase ketuntasan klasikal sudah sesuai dengan yang diharapkan yaitu $100 \%$. Sehingga penelitian dapat dihentikan. Artinya tidak perlu diadakan siklus III.

Temuan yang diperoleh pada pelaksanaan tindakan siklus I dan siklus II yaitu pada siklus I pertemu-an pertama dan kedua diperoleh temuan meliputi (1) guru masih belum bisa mengkondisikan dan menguasai kelas dengan baik, (2) aktivitas guru masih kurang maksimal, terdapat beberapa langkah kegiatan yang terlewat dan kurang tampak yaitu guru melewatkan menyampaikan tujuan pembelajaran, (3) pada kegiatan inti, kekurangan dari aktivitas guru yaitu 
guru kurang memantau setiap kelompok secara merata, 4) permasalahan yang terjadi dari aktivitas siswa yaitu siswa juga masih belum terbiasa bekerjasama dalam kelompok serta ada beberapa siswa yang mengeluhkan pembagian kelompok, 5) guru kurang mengantisipasi masalah yang akan muncul dari ketertarikan berlebih siswa terhadap media pembelajaran yang digunakan, situasi kondusif siswa terpecah karena siswa tertarik dengan media kubus coklat yang dibagikan, siswa juga masih menggunakan media untuk bermain-main, 6) pada kegiatan akhir, guru melewatkan melakukan tanya jawab dengan siswa tentang materi yang belum dipahami, dan 7) hasil belajar siswa sudah mengalami peningkatan dibandingkan pratindakan, meskipun belum mencapai kentuntasan yang diharapkan. Dari temuan tersebut dapat disimpulkan bahwa diperlukan tindakan lebih lanjut untuk menyelesaikan permasalahan yang muncul pada siklus I.

Pada siklus II, kegiatan pembelajaran mengalami peningkatan. Permasalahan yang muncul pada siklus I sudah diatasi oleh guru pada tindakan siklus II. Pada siklus II diperoleh beberapa temuan selama kegiatan pembelajaran meliputi: 1) aktivitas guru selama melaksanakan kegiatan pembelajaran pada siklus II pertemuan pertama dan kedua sudah mengalami peningkatan serta sudah sesuai dengan langkah-langkah pembelajaran menggunakan model experiental learning, 2) guru sudah mulai mampu mengkondisikan dan menguasai kelas, 3) siswa sudah mulai terbiasa bekerja secara kelompok setelah melakukan 2 kali pertemuan sebelumnya, mereka telah melakukan tugas secara kelompok, 4) situasi kelas saat guru membagikan media sudah tertib, karena guru sudah bisa mencegah masalah yang muncul pada siklus I dengan memberikan arahan dan penjelasan yang jelas terlebih dulu kepada siswa tentang media pembelajaran yang digunakan, 5) media pembelajaran sudah tidak digunakan untuk mainan, karena guru sudah memberikan arahan untuk menempatkan media yang sudah tidak digunakan ditengah-tengah semua anggota kelompok, dan 6) hasil belajar siswa pada siklus II ini mengalami peningkatan dibandingkan pada siklus I, persentase ketuntasan klasikal sudah sesuai dengan yang diharapkan yaitu $100 \%$.

\section{PEMBAHASAN}

Model experiental learning yang diterapkan pada pembelajaran matematika materi volume bangun ruang kubus dan balok di kelas V SDN Babadan 02 Kabupaten Blitar berjalan sesuai dengan perencanaan. Penelitian dilaksanakan dengan dua siklus, setiap siklus terdiri dari dua pertemuan dengan alokasi waktu 3 x 35 menit setiap pertemuan.

Persentase keterlaksanaan model experietal learning pada pembelajaran matematika oleh guru sudah sesuai langkah-langkahnya. Pada siklus I rata-rata persentase aktivitas guru dalam menerapkan model experiental learning sebesar 82\% dengan kriteria keberhasilan tindakan baik. Pencapaian rata-rata siklus I sudah baik, tetapi masih ada beberapa langkah yang terdapat dalam RPP terlewatkan. Pada pertemuan pertama guru belum mampu mengkondisikan siswa, saat kegiatan awal guru belum me-nyampaikan tujuan pembelajaran, pada kegiatan inti guru masih belum mampu memantau atau membimbing seluruh kelompok, pada kegiatan akhir guru belum melakukan tanya jawab dengan siswa tentang materi yang belum dipahami dan juga guru belum melakukan refleksi.

Pada siklus II, rata-rata persentase aktivitas guru meningkat mencapai 94.5\% dengan kriteria kebehasilan tindakan sangat baik. Pencapaian peningkatan aktivitas guru dari siklus I ke siklus II mencapai $12.5 \%$. Kenaikan ini terjadi karena pembelajaran yang di-laksanakan sudah mengalami perbaikan dan sesuai dengan langkah-langkah model experiental learning yang diungkapkan Sudrajat (Munif 2009) yaitu Concrete experience, Observation and reflection, Forming abstract concepts, dan Testing in new situation dengan baik serta tidak ada yang terlewatkan.

Aktivitas siswa pada model experiental learning yaitu, pada siklus I rata-rata sebesar $80 \%$ dengan kriteria keberhasilan tindakan baik. Pencapaian rata-rata ini masih belum maksimal karena 
terdapat beberapa permasalahan yang muncul selama tindakan yaitu siswa masih kesulitan beradaptasi dengan pembelajaran secara kelompok dan menggunakan model experiental learning dalam pembelajaran matematika. Kegiatan kerja kelompok berjalan kurang kondusif, siswa ramai tidak ingin dikelompok-kelompokkan bersama teman yang tidak sesuai dengan keinginan mereka.

Selama proses pengerjaan tugas kelompok, ada beberapa kelompok yang belum mampu mengikuti langkah-langkah yang ada dalam Lembar Kerja Kelompok (LKK) dan perlu bimbingan guru. Penggunaan media pembelajaran juga masih belum maksimal, karena ada beberapa siswa yang menggunakan media pembelajaran untuk bermain-main. Saat presentasi di depan kelas, siswa perlu dibimbing dan ditunjuk agar mampu mempresentasikan hasil diskusi mereka.

Pada siklus II, diperoleh peningkatan rata-rata aktivitas siswa sebesar 91\% dengan kriteria sangat baik. Pencapaian peningkatan aktivitas siswa dari siklus I ke siklus II mencapai 11\%, peningkatan ini terjadi karena siswa sudah mampu bekerjasama dengan anggota kelompoknya, dan dapat mengerjakan LKK dengan baik serta menggunakan media pembelajaran untuk men-dukung pembelajaran. Kegiatan ini sesuai dengan pendapat Sanjaya (Irawati 2015) yaitu siswa belajar secara langsung (experiental learning) dalam proses pembelajaran secara langsung, konsep dan prinsip bisa dilakukan dalam bentuk kerjasama dan interaksi dalam kelompok.

Peningkatan aktivitas siswa tersebut terjadi juga karena didukung bertambahnya keaktifan dan keberanian siswa selama proses pembelajaran, serta siswa mulai terbiasa dengan pembelajaran model experiental learning yang membuat siswa sudah bisa mengerjakan lembar kegiatan yang diberikan oleh guru secara mandiri. Hal ini sesuai kelebihan model experiental learning bahwa "kegiatan belajar mengajar dapat berlangsung secara aktif dan menyenangkan, memberikan pembelajaran yang berkesan dan mendalam kepada siswa melalui pengalaman sehingga konsep tertanam dengan kuat, membentuk karakter siswa yang cerdas dan mandiri, karena siswa diajarkan untuk membangun sendiri pe-ngetahuannya melalui pengalaman yang diperolehnya" (Jatmiko 2015). Peningkatan tersebut membuktikan bahwa dengan menerapkan model experiental learning dapat meningkatkan aktivitas siswa pada pembelajaran matematika materi volume bangun ruang kubus dan balok pada siswa kelas V.

Berdasarkan hasil penelitian yang dilakukan mulai dari pratindakan, siklus I dan siklus II, diketahui bahwa penerapan model experiental learning pada siswa kelas V dapat meningkatkan hasil belajar siswa mata pelajaran matematika materi volume bangun ruang kubus dan balok.

Hasil belajar siswa kelas V mulai tahap pratindakan, siklus I, dan siklus II terus mengalami peningkatan. Pada tahap pratindakan, nilai rata-rata siswa hanya mencapai 53 dengan ketuntasan $35 \%$. Hasil belajar siswa aspek pengetahuan, pada siklus I pertemuan pertama diperoleh persentase ketuntasan hasil belajar siswa mencapai $70 \%$ (cukup). Sedangkan persentase ketuntasan siswa pada siklus I pertemuan kedua meningkat mencapai $82 \%$ (baik).

Hasil belajar siswa aspek pengetahuan, pada siklus II pertemuan pertama diperoleh persentase ketuntasan hasil belajar siswa mencapai $88 \%$ (baik). Sedangkan pada siklus II pertemuan kedua ketuntasan $100 \%$ (sangat baik) yang artinya semua siswa atau 17 siswa sudah tuntas memperoleh nilai di atas 72 .

Berdasarkan hasil penelitian tersebut dapat diketahui bahwa adanya peningkatan belajar matematika materi volume bangun ruang kubus dan balok pada siswa kelas V SDN Babadan 02 setelah dilakukan model experiental learning. Hal ini sesuai dengan hakikat model experiental learning menurut Kolb (Fathurrohman 2015) yaitu Jika seseorang terlibat aktif dalam proses belajar maka orang itu akan belajar jauh lebih baik. Peningkatan hasil belajar mata pelajaran matematika menggunakan model experiental learning, ini juga sesuai dengan penelitian terdahulu yang dilakukan oleh (Lestari 2017) yang menunjukkan adanya peningkatan hasil belajar matematika KPK 
dan FPB melalui model experiental learning pada siswa kelas IV SDN 2 Gandusari Kabupaten Trenggalek.

Dengan demikian, hasil penelitian ini sesuai dengan hasil penelitian (Sholihah and Mahmudi 2015), (Vinayanti and Fadhillah 2019), (Sholihah, Shanti, and Abdullah 2019), dan (Paramita, Suharta, and Gita 2019) tentang penerapan dan pengaruh model experiental learning dapat meningkatkan aktivitas, kemampuan berpikir, motivasi, dan prestasi belajar siswa, serta dapat membantu guru untuk memperbaiki dan meningkatkan kualitas proses pembelajaran di kelas.

\section{SIMPULAN}

Penerapan model experiental learning pada materi volume bangun ruang kubus dan balok dapat dilaksanakan oleh guru dan siswa dengan baik, berjalan dengan lancar, dan sudah sesuai dengan langkah-langkah model pembelajaran experiental learning. Berdasarkan pengamatan dalam menggunakan model experiental learning, aktivitas siswa dan guru dalam mengikuti kegiatan pembelajaran matematika materi volume bangun ruang kubus dan balok mengalami peningkatan. Hal ini terbukti dari rata-rata persentase aktivitas guru dan siswa meningkat dari siklus I ke siklus II dengan kriteria sangat baik.

Bukan hanya pada aktivitas guru dan siswa, dengan penerapan model pembelajaran experiental learning dapat meningkatkan hasil belajar siswa pada mata pelajaran matematika materi volume bangun ruang kubus dan balok di kelas V SDN Babadan 02 menjadi lebih baik. Hal ini dibuktikan dari data hasil belajar siswa yang mengalami peningkatan pada siklus I nilai rata-rata kelas meningkat menjadi 80.5 dan persentase ketuntasan klasikal sebesar 82\% Pada siklus II nilai rata-rata kelas mencapai 90.8 dan ketuntasan klasikal mencapai $100 \%$ yang artinya semua siswa sudah mencapai nilai KKM. Dengan demikian penerapan model experiental learning pada materi volume bangun ruang kubus dan balok dapat meningkatkan aktivitas siswa dan guru, serta dapat meningkatkan hasil belajar siswa.

\section{DAFTAR RUJUKAN}

Arikunto, Suharsimi, and Supardi Suhardjono. (2014). "Penelitian Tindakan Kelas.(Cetakan Kedua Belas)." Jakarta: Bumi Aksara.

Fathurrohman, M. (2015). "Model-Model Pembelajaran Inovatif (Pertama; N. Hidayah, Ed.)." Jogjakarta: Ar-Ruzz Media.

Irawati, Rita. (2015). "Pengaruh Penerapan Model Experiential Learning Terhadap Hasil Belajar IPS Siswa Kelas IV SD Negeri Seyegan Pundong Bantul.” E-Jurnal Skripsi Program Studi Teknologi Pendidikan 5(1).

Jatmiko, Danang. (2015). "Peningkatan Prestasi Belajar IPA Materi Benda dan Sifatnya dengan Model Experiential Learning pada Siswa Kelas III B di MI Ma'arif Mangunsari Salatiga Tahun Pelajaran 2014/2015." PhD Thesis, IAIN Salatiga.

Lestari, Yanu Indah. (2017). "Peningkatan Hasil Belajar Matematika KPK Dan FPB Melalui Model Experriental Learning Pada Siswa Kelas IV SDN 2 Gandusari Kabupaten Trenggalek." SKRIPSI Jurusan Kependidikan Sekolah Dasar \& Prasekolah-Fakultas Ilmu Pendidikan UM.

Munif, I. R. S. (2009). "Penerapan Metode Experiential Learning Pada Pembelajaran IPA Untuk Meningkatkan Hasil Belajar Siswa Sekolah Dasar." Jurnal Pendidikan Fisika Indonesia 5(2).

Paramita, Putu Yulia, I. Gusti Putu Suharta, and I. Nyoman Gita. (2019). "Pengaruh Model Experiential Learning terhadap Motivasi dan Prestasi Belajar Matematika Siswa Kelas VIII SMP Negeri 1 Sawan.” Jurnal Pendidikan Matematika Undiksha 10(2):19-25.

Perdana, Kistin Restu, M. Zainuddin, and Yuniawatika Yuniawatika. (2018). "Pembelajaran Matematika Model Guided Inquiry Untuk Meningkatkan Hasil Belajar Siswa Sekolah Dasar." Wahana Sekolah Dasar 26(2):43-50. 
Retnowati, Dwi, and Murtiyasa Budi. (2013). "Upaya Meningkatkan Pemahaman Konsep Dan Disposisi Matematis Menggunakan Model Pembelajaran Treffinger."

Sholihah, Dyahsih Alin, and Ali Mahmudi. (2015). "Keefektifan Experiential Learning Pembelajaran Matematika MTs Materi Bangun Ruang Sisi Datar." Jurnal Riset Pendidikan Matematika 2(2):175-185.

Sholihah, Dyahsih Alin, Widha Nur Shanti, and Ahmad Anis Abdullah. (2019). "Model Experiential Learning Untuk Meningkatkan Kemampuan Berpikir Kritis Mahasiswa Pendidikan Matematika." UNION: Jurnal Ilmiah Pendidikan Matematika 7(3):383-390.

Sugiyono, S. 2015. "Metode Penelitian Pendidikan Pendekatan Kuantitatif, Dan R\&D." Alfabeta Bandung.

Vinayanti, Antik, and Fika Muji Fadhillah. (2019). "Implementation of Experiental Learning Models to Improve Reasoning Ability of Student's SMP." (JIML) Journal of Innovative Mathematics Learning 2(1):1-8. 